\title{
PENGARUH MODEL PEMBELAJARAN SAINS TEKNOLOGI MASYARAKAT TERHADAP KEMAMPUAN BERPIKIR KRITIS DAN SIKAP ILMIAH PADA SISWA KELAS VIII SMP NEGERI 2 KUBU
}

\author{
Luh Putu Purnama Dewi, I Wayan Santyasa, I Made Kirna \\ Program Studi Teknologi Pembelajaran, Program Pasca Sarjana \\ Universitas Pendidikan Ganesha \\ Singaraja, Indonesia
}

e-mail: purnamadewi.luhputu@gmail.com, santyasa@yahoo.com, made.kirna@pasca.undiksha.ac.id

\begin{abstract}
ABSTRAK
Penelitian ini bertujuan mendeskripsikan (1) perbedaan kemampuan berpikir kritis (KBK) dan sikap ilmiah (SI) antara siswa yang belajar dengan model pembelajaran STM dan yang belajar dengan model pembelajaran langsung (PL) setelah perlakuan dikontrol dengan kemampuan berpikir kritis (KBKA) awal dan sikap ilmiah awal (SIA), (2) perbedaan KBK antara siswa yang belajar dengan model pembelajaran STM dan yang belajar dengan model PL setelah perlakuan dikontrol dengan KBKA dan SIA, (3) perbedaan SI antara siswa yang belajar dengan model pembelajaran STM dan yang belajar dengan model PL setelah perlakuan dikontrol dengan KBKA dan SIA. Penelitian eksperimen semu ini menggunakan non-equivalent pretest posttest control group design. Populasinya adalah 8 kelas siswa kelas VIII SMP Negeri 2 Kubu Tahun Pelajaran 2016/2017 dengan jumlah siswa 252 orang. Sampel penelitian dipilih secara simple random untuk menentukan 2 kelas, yang selanjutnya dirandom kembali untuk menentukan 1 kelas sebagai kelompok eksperimen menggunakan pembelajaran STM dan yang lain pembelajaran PL. Data KBK dikumpulkan dengan tes dan data SI dengan kuesioner baik di awal maupun di akhir eksperimen. Data dianalisis menggunakan statistik deskriptif dan MANCOVA. Setelah perlakuan dikontrol dengan KBKA dan SIA, hasil penelitian menunjukkan temuan-temuan sebagai berikut. (1) Terdapat perbedaan secara signifikan KBK dan SI antara siswa yang belajar dengan model pembelajaran STM dan yang belajar dengan model PL. KBK dan SI siswa yang belajar dengan pembelajaran STM lebih tinggi dibandingkan dengan yang beljar dengan model PL. (2) Terdapat perbedaan KBK antara siswa yang belajar dengan model pembelajaran STM dan yang belajar dengan model PL. KBK siswa yang belajar dengan pembelajaran STM lebih tinggi dibandingkan dengan yang beljar dengan model PL. (3) Terdapat perbedaan SI antara siswa yang belajar dengan model pembelajaran STM dan siswa yang belajar dengan model. SI siswa yang belajar dengan pembelajaran STM lebih tinggi dibandingkan dengan yang beljar dengan model PL.
\end{abstract}

Kata kunci: Model Sains Teknologi Masyarakat, Kemampuan Berpikir Kritis, Sikap Imiah

ABSTRACT
This study aims at describing 1) the difference of both students' critical thinking skill (CTS) and their
scientific attitudes (SA) between them learned in the Science-Technology-Society (STS) model and in
Direct Instructional (DI) model after the treatment was controlled by both prior CTS and early SA, 2)
the difference of students' CTS between them learned in the STS and in the DI models after the
treatment was controlled by both prior CTS and early SA, and 3) the difference of students' SA
between them learned in the STS and in the DI models after the treatment was cnotrolled by both
prior CTS and early SA. This quasi experiment used non-equivalent pretest posttest control group
design. The population of the study was 8 classes of eight grade students of SMP Negeri 2 Kubu in
the academic year 2016/2017 which comprised of 252 students. The samples of 2 classes were
choosen by simple random sampling to determent the first class as an experiment group utilized STS
and the othe one used DI models. The data of CTS was collected by test and the data of SA by
questionnaire. To analyze of the data, the descriptive and the MANCOVA statistics were used. To test
the hypothesis, a significant level of $5 \%$ was utilized. After the treatment was cotrolled by both prior
CTS and early SA,the results of the study were aas follows. (1) There is a significant difference both 
CTS and SA between students learned in the STS and them the DI models. Both CTS and SA of students learned in the STS is higher than them in the DI models. (2) There is a significant difference CTS between students learned in the STS and them the DI models. The CTS of students learned in the STS is higher than them in the DI models. 3) There is a significant difference SA between students learned in the STS and them the DI models. The SA of students learned in the STS is higher than them in the DI models.

Keywords: Science technology society learning model, critical thinking skills and scientific attitudes

\section{PENDAHULUAN}

Pendidikan memiliki peran yang sangat penting dalam pembentukan Sumber Daya Manusia (SDM) berkualitas yang mampu mengikuti persaingan dalam era globalisasi ini. Pendidikan nasional berfungsi mengembangkan kemampuan dan membentuk watak serta peradaban bangsa yang bermartabat dalam rangka mencerdaskan kehidupan bangsa, yang bertujuan untuk berkembangnya potensi siswa agar menjadi manusia yang beriman dan bertaqwa kepada Tuhan Yang Maha Esa, berakhlak mulia, sehat, berilmu, cakap, kreatif, mandiri, dan menjadi warga negara yang demokratis serta bertanggung jawab (UU RI Nomor 20 tahun 2003 tentang Sisdiknas). Hal ini tentu didukung oleh lembaga pendidikan yang baik dengan menampilkan konsep manajemen dan administrasi yang berkembang dewasa ini, adanya upaya dalam pengelolaan perbaikan proses pembelajaran dengan tetap mengikuti perubahan paradigma baru dalam bidang pendidikan sehingga mendorong peserta didik agar sanggup bersaing di era global, dan bermasyarakat. Kemampuan pada persaingan global salah satu dipengaruhi oleh kemampuan kualitas sains, dan keterampilan sains. Kualitas pendidikan sains sangat ditentukan oleh kualitas sumber daya manusia.

Pendidikan sains pada hakikatnya adalah membelajarkan peserta didik untuk memahami hakikat sains (proses, produk dan sikap). Sains sebagai sebuah produk karena terdiri dari sekumpulan pengetahuan yang berupa fakta-fakta, konsep-konsep, prinsip dan hukum tentang gejala alam. Sains sebagai sebuah produk, karena merupakan suatu rangkaian kegiatan yang terstruktur dan sistematis yang dilakukan untuk menemukan konsep, prinsip dan hukum tentang gejala alam. Sedangkan sains sebagai suatu sikap, karena diharapkan mampu menimbulkan karakter bagi siswa sesuai dengan nilai siswa. Pendidikan sains (IPA) umumnya memiliki peranan penting dalam menghasilkan peserta didik yang berkualitas, yaitu peserta didik yang mampu berpikir kritis, kreatif, logis, dan berinisiatif dalam menanggapi isu di masyarakat yang diakibatkan oleh dampak perkembangan ilmu pengetahuan atau sains dan teknologi (IPTEK).

Namun kenyataan yang terjadi pada lembaga-lembaga pendidikan di Indonesia, terutama pada jenjang sekolah dasar dan menengah adalah guru masih kurang memperhatikan aspek keterampilan berpikir dalam proses pembelajaran (Corebima dalam Nasir, et al, 2015). Siswa hanya difokuskan pada kegiatan menghafal materi pelajaran. Ketika siswa dihadapkan pada permasalahan yang terjadi di lingkungan sekitarnya, siswa kurang mampu menggabungkan pengetahuan yang dimilikinya untuk mencari penjelasan dan memberikan pendapat berupa solusi dari masalah tersebut menggunakan kemampuan berpikir kritis dan kemampuan berargumen.

Secara nasional, kondisi pendidikan Indonesia ini sangat memprihatinkan. Nilai prestasi literasi membaca, matematika, dan sains siswa Indonesia berada signifikan di bawah rata-rata internasional. Untuk literasi membaca, Indonesia pada Tahun 2012 berada pada peringkat 61 dari 65 negara. Untuk rata-rata skor prestasi literasi matematika, posisi Indonesia berada pada peringkat 64 dari 65 negara. Begitu pula untuk rata-rata skor prestasi litersai sains, posisi 
Indonesia masih jauh di bawah rata-rata internasional. Siswa Indonesia pada Tahun 2012 berada pada peringkat 64 dari 65 negara (litbang.kemdikbud.go.id). Data Programme for International Student Assesment (PISA) tahun 2006, menunjukkan bahwa $66,6 \%$ pelajar Indonesia memiliki pengetahuan sains yang sangat terbatas, sedangkan yang memiliki kemampuan melakukan penelitian sederhana sebanyak $27,5 \%$. Persentase pelajar yang memiliki kemampuan mengidentifikasi masalahmasalah ilmiah hanya $9,5 \%$, sedangkan yang mampu memanfaatkan sains untuk kehidupan sehari-hari hanya 1,4\%. Berdasarkan jumlah skor sains, didapatkan bahwa siswa di Indonesia hanya mendapatkan skor 383. Sedangkan skor negara-negara lain seperti : Cina mendapat skor 520 dan Australia mendapatkan skor 527.

Hasil PISA tersebut seharusnya dijadikan acuan bahwa pendidikan Sains di Indonesia belum mampu meningkatkan keterampilan proses sains siswa, yang berdampak pada rendahnya kemampuan mengaitkan konsep dengan konteks kehidupan sehari-hari. Dengan predikat ini bisa mencerminkan bagaimana sistem pendidikan Indonesia yang sedang berjalan saat ini untuk penampilan membaca, matematika dan sains. Khusus untuk kemampuan scientific literacy, rendahnya kemampuan anak bangsa juga didukung oleh data dari penilaian Trends in International Mathematics and Science Study (TIMSS). Berdasarkan data prestasi sains di TIMSS tahun 2011, Indonesia berada pada urutan 40 dari 42 negara.

Rendahnya nilai siswa Indonesia dalam tes yang dilakukan PISA dan TIMSS disebabkan oleh faktor-faktor berikut. Pertama, kondisi di lapangan masih menunjukkan bahwa pembelajaran yang dilakukan guru secara umum masih bersifat teacher centered, sehingga guru menjadi satu-satunya sumber belajar bagi siswa. Kedua, guru pada umumnya mengajar lebih banyak menggunakan metode ceramah, tidak mengaitkan pembelajaran dengan isu-isu atau fenomena dan permasalahan dalam kehidupan nyata siswa sehari-hari. Hal tersebut menyebabkan siswa lebih bersifat pasif karena mereka tidak terlibat langsung mencari informasi yang mereka butuhkan dalam belajar. Ketiga, siswa belum bisa mengaitkan pengetahuan sains yang mereka miliki dengan isu-isu sains dalam kehidupan sehari-hari, dan antara sains dengan teknologi yang merupakan hasil dari sains itu sendiri. Keempat, guru mengembangkan tes masih berorientasi pada materi yang ada di buku, tanpa mengaitkan dengan situasi nyata dalam kehidupan sehari-hari. Hasil tes siswa belum dijadikan sebagai bahan refleksi bagi perbaikan pembelajaran, dan ruang lingkup tes masih bertumpu pada aspek pengetahuan terutama unsur mengingat (recall). Kelima, pembelajaran yang dilaksanakan kurang melatih kemampuan berpikir kritis sehingga siswa menjadi kurang bisa menyikapi perkembangan IPTEKS, tidak mampu menyelesaikan permasalahan yang dihadapi dalam kehidupan nyata, tidak bisa menjawab soal-soal level tinggi yang berkaitan dengan keterampilan berpikir kritis dalam tes yang dilakukan oleh PISA dan TIMSS (Desianti, et al, 2015).

Kenyataan yang terjadi selama ini di SMP Negeri 2 Kubu menunjukkan siswa kurang berani bertanya atau mengembangkan pendapatnya saat pelajaran berlangsung. Hal ini dikarenakan siswa tidak terbiasa untuk mengungkapkan pendapatnya, selain itu sikap pasif yang diperlihatkan siswa disebabkan karena pelajaran IPA yang diajarkan merupakan sesuatu yang masih abstrak. Pembelajaran yang berlangsung kurang menghubungkan isi pembelajaran dengan kenyataan sehingga siswa kurang paham terhadap materi yang disampaikan. Hal ini menyebabkan proses pembelajaran belum dapat menggali secara maksimal kemamuan berpikir siswa. Sikap siswa terhadap pembelajaran sains juga perlu di soroti. Sikap siswa dapat dilihat melalui prilaku atau tindakan siswa dalam pembelajaran sains di kelas dan keaktifan siswa dalam kegiatan pembelajaran. Aspek sikap memiliki pengaruh yang besar dalam 
pembelajaran sains, karena sikap ilmiah siswa dapat mempengaruhi pilihan tindakan yang akan dilakukan siswa.

Penelitian yang dilakukan oleh Kartini, et al (2015) juga menunjukkan bahwa rendahnya hasil belajar IPA siswa di siswa kelas XI IPA di SMA Pariwisata Saraswati Klungkung disebabkan karena keadaan siswa yang heterogen di dalam kelas. Kurangnya keterlibatan siswa dalam proses belajar juga mempengaruhi hasil belajar. Hasil belajar yang diperoleh berkaitan dengan sikap siswa dalam proses pembelajaran yang berlangsung. Sikap ilmiah diperlukan siswa untuk membantu perkembangan pola pikir siswa.

Para penganut konstruktivistik menganggap bahwa mengajar bukanlah kegiatan memindahkan pengetahuan dari guru ke siswa melainkan suatu kegiatan yang memungkinkan siswa membangun sendiri pengetahuan, sikap, dan keterampilannya melalui aktivitas-aktivitas praktik. Jelas bahwa pengetahuan awal mempunyai peran yang cukup penting dalam proses belajar.

Upaya peningkatan kualitas pendidikan seharusnya dimulai dari pembenahan kemampuan guru untuk mengembangkan silabus dan membuat perencanaan pembelajaran yang tepat. Kemampuan yang dimaksud juga merancang suatu strategi pembelajaran dan memilih model yang sesuai dengan tujuan pembelajaran sains. Depdiknas (2005), menyebutkan bahwa pendidikan harus mengembangkan eksistensi peserta didik seoptimal mungkin melalui fasilitasi yang dilaksanakan melalui proses pendidikan yang bermartabat, properubahan (kreatif, inovatif, dan eksperimentatif), menumbuhkan dan mengembangkan bakat minat, dan kemampuan peserta didik. Ini berarti menuntut guru aktif dalam menciptakan perubahan serta bersedia mengakomodir berbagai perubahan yang terjadi.

Sejalan dengan tujuan pendidikan nasional, Program Studi Teknologi Pembelajaran harus mampu mengembangkan eksistensinya dalam pengembangan pemebelajaran yang aktif, kreatif, dan inovatif. Pengembangan pembelajaran ini juga tidak terlepas dari teori konstruktivistik, dan mengubah paradigma lama bahwa pembelajaran yang berpusat pada guru menjadi pembelajaran yang berpusat pada siswa. Teknologi pembelajaran diharapkan mampu membawa informasi-informasi langsung pada pelajar. Sekolah masa depan akan terasa dekat atau jauh tergantung pada guru yang mengintegrasikan teknologi dalam pembelajaran, dan menggunakan teknologi untuk menambah pembelajaran dan pencapaian siswa (Hall, Quin \& Gulnick, 2008). Dengan demikian model pembelajaran sians teknologi masyarakat dapat dijadikan suatu alternatif model pembelajaran yang bersifat aktif, kreatif, dan inovatif dalam teknologi pembelajaran.

Model pembelajaran sains teknologi masyarakat digunakan dalam penelitian ini karena memiliki beberapa keunggulan antara lain; 1) peserta didik dapat menghubungkan sains yang dipelajari dengan kehidupan sehari-hari, 2) peserta didik menjadi terlibat dalam isuisu sosial, 3) dapat melihat manfaat dari belajar sains untuk menjadi warga Negara yang bertanggung jawab, 4) peserta didik menginginkan informasi yang berhubungan dengan masalah, serta tertarik dengan perkembangan teknologi barudan menggunakannya untuk melihat kepentingannya serta kecocokannya dengan konsep sains (Yager dalam Sadia, 2011).

Pembelajaran IPA dengan menggunakan model sains teknologi masyarakat diharapkan dapat menjembatani kesenjangan antara pembelajaran IPA di dalam kelas dengan kemajuan teknologi dan perkembangan masyarakat yang ada di sekitar peserta didik. Melalui model pembelajaran ini, peserta didik juga dilatih untuk membiasakan diri bersikap peduli akan masalah-masalah sosial dan lingkungan yang berkaiatan dengan ilmu pengetahuan dan teknologi serta mampu memecahkan masalah, mengambil keputusan dan menganalisis isu-isu sains 
dan teknologi dalam masyarakat. Oleh karena itu, perlu dilakukan penelitian tentang "Pengaruh Model Pembelajaran Sains Teknologi Masyarakat terhadap Kemampuan Berpikir Kritis dan Sikap IImiah pada Siswa Kelas VIII SMP Negeri 2 Kubu".

Berdasarkan latar belakang
masalah tersebut, penelitian ini memusatkan perhatian untuk menjawab tiga rumusan masalah. (1) Apakah terdapat perbedaan kemampuan berpikir kritis dan sikap ilmiah secara bersamasama antara siswa yang belajar dengan model pembelajaran sains teknologi masyarakat dan siswa yang mengikuti pembelajaran langsung setelah perlakuan dikontrol dengan kemampuan berpikir kritis awal dan sikap ilmiah awal? (2) Apakah terdapat perbedaan kemampuan berpikir kritis antara siswa yang belajar dengan model pembelajaran sains teknologi masyarakat dan siswa yang mengikuti pembelajaran langsung setelah perlakuan dikontrol dengan kemampuan berpikir kritis awal? (3) Apakah terdapat perbedaan sikap ilmiah antara siswa yang belajar dengan model pembelajaran sains teknologi masyarakat dan siswa yang mengikuti pembelajaran langsung setelah perlakuan dikontrol dengan sikap ilmiah awal?

\section{METODE}

Jenis penelitian yang dilaksanakan adalah eksperimen semu dengan rancangan non-equivalent pretest-posttest control group design. Populasi penelitian ini adalah 8 kelas siswa kelas VIII SMP Negeri 2 Kubu Th. Pelajaran 2016/2017. Pengambilan sampel dilakukan dengan teknik group random sampling. Berdasarkan hasil undian diperoleh kelas VIII $(H)$ sebagai kelompok eksperimen dan kelas VIII(D) sebagai kelompok kontrol.

Variabel bebas dalam penelitian ini adalah model pembelajaran dengan dua level, yaitu model pembelajaran Sains Teknologi Masyarakat dan model pembelajaran langsung. Variabel terikat nya adalah kemampuan berpikir kritis dan sikap ilmiah. Data kemampuan berpikir kritis dan sikap ilmiah secara berturut-turut diukur dengan tes kemampuan berpikir kritis dan kuisioner sikap ilmiah. Aspekaspek yang diukur dalam kemampuan berpikir kritis meliputi merumuskan masalah, memberikan argument, melakukan deduksi, melakukan induksi, melakukan evaluasi, memutuskan dan melaksanakan. Kriteria penilaian tes kemampuan berpikir kritis menggunakan rubrik yang memiliki rentangan skor 0 5.Tes kemampuan kemampuan berpikir kritis berbentuk soal uraian yang terdiri dari 10 butir soal dengan indeks konsistensi internal butir $(r)$ bergerak dari 0,448 s.d 0,862 dan indeks reliabelitas tes Alpha Cronbach sebesar 0,861 dengan klasifikasi sangat tinggi.

Aspek-aspek yang diukur dalam sikap ilmiah meliputi sikap ingin tahu, sikap respek terhadap data, sikap berpikir kritis, sikap penemuan dan kreativitas, sikap berpikiran terbuka dan kerjasama, sikap ketekunan, dan sikap peka terhadap lingkungan sekitar. Teknik pemberian skor pada tiap butir angket sikap ilmiah menggunakan skala Likert 1-5. Kuesioner sikap ilmiah terdiri dari 34 butir dengan indeks kosistensi internal butir $(r)$ bergerak dari 0,311 s.d 0,691 dan indeks reliabelitas tes Alpha Cronbach sebesar 0,899 dengan klasifikasi sangat tinggi.

Data dianalisis secara deskriptif dan Multivariat Analysis of Covarian (MANCOVA). Analisis deskriptif digunakan untuk mendeskripsikan nilai rata-rata dan simpangan baku kemampuan berpikir kritis dan sikap ilmiah. Pengujian hipotesis penelitian digunakan MANCOVA. Sebelumnya, dilakukan uji normalitas, uji homogenitas data, uji homogenitas matriks varian/covarians, uji linieritas, dan uji kolinearitas antara dua variabel terikat. Program yang digunakan untuk analisis data adalah SPSS 16.0 for Windows dengan pengujian hipotesis pada taraf signifikansi 5\%.

\section{HASIL DAN PEMBAHASAN}

Deskripsi umum hasil penelitian yang dipaparkan adalah deskripsi nilai kemampuan berpikir kritis awal siswa, nilai sikap ilmiah awal, nilai kemampuan 
Tabel 1. Rekapitulasi hasil analisis data berpikir kritis dan sikap ilmiah

\begin{tabular}{|c|c|c|c|c|c|c|c|c|}
\hline \multirow{2}{*}{ Statistik } & \multicolumn{4}{|c|}{$A_{1}$} & \multicolumn{4}{|c|}{$\mathrm{A}_{2}$} \\
\hline & $\mathrm{X}_{11}$ & $X_{12}$ & $Y_{11}$ & $Y_{12}$ & $X_{21}$ & $X_{22}$ & $\mathrm{Y}_{21}$ & $\mathrm{Y}_{22}$ \\
\hline $\begin{array}{l}\text { Banyak } \\
\text { Data (n) }\end{array}$ & 30 & 30 & 30 & 30 & 30 & 30 & 30 & 30 \\
\hline Jumlah & & & & & & & & \\
\hline Data & 1308 & 2116 & 2328 & 2651 & 1038 & 1995 & 1926 & 2110 \\
\hline Nilai Mak & 74,00 & 84,00 & 95.00 & 98,00 & 65,00 & 84,00 & 78,00 & 84,00 \\
\hline Nilai Min & 13,00 & 56,00 & 60,00 & 76,00 & 4.00 & 55.00 & 50.00 & 59,00 \\
\hline Range & 61,00 & 28,00 & 35,00 & 22.00 & 61,00 & 29,00 & 28,00 & 23,00 \\
\hline Mean & 43,60 & 70,53 & 77,60 & 88,37 & 34,60 & 66,50 & 64,20 & 70,33 \\
\hline Median & 42,50 & 71,00 & 78,00 & 88,50 & 33,50 & 65,00 & 65,00 & 70,50 \\
\hline Modus & 35,00 & 72,00 & 80,00 & 82,00 & 26,00 & 65,00 & 65,00 & 60,00 \\
\hline $\begin{array}{l}\text { Standar } \\
\text { Deviasi } \\
\text { (S) }\end{array}$ & 15,48 & 6,21 & 8,83 & 6,08 & 15,48 & 7,66 & 8,70 & 5,96 \\
\hline $\begin{array}{l}\text { Varians } \\
\left(\mathrm{S}^{2}\right)\end{array}$ & 239,77 & 38,60 & 77,97 & 36,93 & 239,77 & 58,60 & 75,61 & 35,47 \\
\hline
\end{tabular}

Keterangan: $\mathrm{A}_{1}=$ Model STM, $\mathrm{A}_{2}=$ Model DI, $\mathrm{X}_{11}=$ Hasil pre-test berpikir kritis model STM, $\mathrm{X}_{12}=$ Hasil pre-test sikap ilmiah model STM, $\mathrm{Y}_{11}=$ Hasil post-test berpikir kritis model STM, $\mathrm{Y}_{12}=$ Hasil post-test sikap ilmiah model STM, $\mathrm{X}_{21}=$ Hasil pre-test berpikir kritis model DI , $\mathrm{X}_{22}=$ Hasil pre-test sikap ilmiah model DI, $\mathrm{Y}_{21}=$ Hasil post-test berpikir kritis model DI, dan $\mathrm{Y}_{22}=$ Hasil post-test sikap ilmiah model DI.

Pada Tabel 1, tampak bahwa setelah perlakukan kelompok MPSTM menunjukkan pencapaian kemampuan berpikir kritis dan sikap ilmiah lebih baik dibandingkan dengan kelompok MPL.

Hasil pengujian normalitas data menggunakan statistik KolmogiorovSmirnov menunjukkan bahwa nilai-nilai statistik yang diperoleh memiliki angka signifikansi lebih besar dari 0.05. Hal ini menunjukkan bahwa sebaran data kemampuan berpikir kritis dan sikap ilmiah berdistribusi normal. Hasil pengujian homogenitas varian mengunakan Levene's Test of Equality of Error Variances untuk kelompok model pembelajaran menunjukkan angka-angka signifikansi statistik Levene lebih besar dari 0,05. Hal ini menunjukkan bahwa varian antar model pembelajaran adalah homogen. Hasil pengujian homogenitas matrik varian menggunakan uji Box's $M$ menunjukkan bahwa Box's $M$ memiliki angka signifikansi sebesar 0,824 dan lebih besar dari 0,05. Hal ini menunjukkan bahwa matriks varian variabel terikat adalah sama. Hasil pengujian linieritas menunjukkan nilai $\mathrm{F}$ pada diviation of linierity memiliki angka signifikan lebih kecil 0,005. Hal ini menunjukkan kovariabel dan variabel terikat merupakan bentuk hubungan regresi linier. Hasil pengujian kolinieritas antar variabel terikat menggunakan korelasi Product Moment menunjukkan bahwa harga $r_{\text {hitung }}$ sebesar 0,766 dan Sig.(2-tailed) 0,001 < 0,05, sehingga variabel kemampuan berpikir kritis dan sikap ilmiah tidak kolinear. Oleh karena uji asumsi telah terpenuhi, selanjutnya dilakukan uji MANCOVA.

Pada penelitian ini diajukan tiga hipotesis. Pengujian hipotesis yang pertama digunakan MANCOVA. Hasil analisis disajikan pada Tabel 2. 
Tabel 2 Rekapitulasi Hasil Uji Multivariat

\begin{tabular}{|ll|r|r|r|r|r|}
\hline Effect & & Value & \multicolumn{1}{c|}{$F$} & Hypothesis $d f$ & Error df & \multicolumn{1}{c|}{ Sig. } \\
\hline Intercept & Pillai's Trace & 0,671 & $55,967^{\mathrm{a}}$ & 2,000 & 55,000 & 0,000 \\
& Wilks' Lambda & 0,329 & $55,967^{\mathrm{a}}$ & 2,000 & 55,000 & 0,000 \\
& Hotelling's Trace & 2,035 & $55,967^{\mathrm{a}}$ & 2,000 & 55,000 & 0,000 \\
& Roy's Largest Root & 2,035 & $55,967^{\mathrm{a}}$ & 2,000 & 55,000 & 0,000 \\
\hline KSI & Pillai's Trace & 0,122 & $3,831^{\mathrm{a}}$ & 2,000 & 55,000 & 0,028 \\
& Wilks' Lambda & 0,878 & $3,831^{\mathrm{a}}$ & 2,000 & 55,000 & 0,028 \\
& Hotelling's Trace & 0,139 & $3,831^{\mathrm{a}}$ & 2,000 & 55,000 & 0,028 \\
& Roy's Largest Root & 0,139 & $3,831^{\mathrm{a}}$ & 2,000 & 55,000 & 0,028 \\
\hline KBK & Pillai's Trace & 0,601 & $41,342^{\mathrm{a}}$ & 2,000 & 55,000 & 0,000 \\
& Wilks' Lambda & 0,399 & $41,342^{\mathrm{a}}$ & 2,000 & 55,000 & 0,000 \\
& Hotelling's Trace & 1,503 & $41,342^{\mathrm{a}}$ & 2,000 & 55,000 & 0,000 \\
& Roy's Largest Root & 1,503 & $41,342^{\mathrm{a}}$ & 2,000 & 55,000 & 0,000 \\
\hline MP & Pillai's Trace & 0,735 & $76,369^{\mathrm{a}}$ & 2,000 & 55,000 & 0,000 \\
& Wilks' Lambda & 0,265 & $76,369^{\mathrm{a}}$ & 2,000 & 55,000 & 0,000 \\
& Hotelling's Trace & 2,777 & $76,369^{\mathrm{a}}$ & 2,000 & 55,000 & 0,000 \\
& Roy's Largest Root & 2,777 & $76,369^{\mathrm{a}}$ & 2,000 & 55,000 & 0,000 \\
\hline
\end{tabular}

Berdasarkan ringkasan analisis MANCOVA yang disajikan pada Tabel 2, dapat diinterpretasikan bahwa nilai-nilai satistik Pillai's Trace, Wilks' Lambda, Hotelling's Trace, dan Roy's Largest Root pada kovariabel sikap ilmiah adalah $\mathrm{F}=$ 3,831 masing-masing dengan angka signifikan 0,028 untuk kovariabel sikap ilmiah $(\mathrm{KSI})$ dan $\mathrm{F}=41,342$ dengan angka-angka signifikansi 0,001 untuk kovariabel berpikir kritis (KBK). Oleh karena angka-angka signifikansi tersebut lebih kecil dari 0,05, maka KBK dan KSI berpengaruh secara signifikan terhadap skor-skor post-test berpikir kritis (BK) dan skor-skor sikap ilmiah (SI).
Pengujian terhadap hipotesi 1 juga menunjukkan bahwa nilai-nilai statistik Pillai's Trace, Wilks' Lambda, Hotelling's Trace, dan Roy's Largest Root adala F = 76,369 dengan angka-angka signifikansi 0,001 yang lebih kecil dari 0,05 , sehingga $\mathrm{H}_{0}$ ke-1 ditolak. Jadi, terdapat perbedaan kemampuan berpikir kritis dan sikap ilmiah antara siswa yang belajar dengan model pembelajaran sains teknologi masyarakat dan yang belajar dengan model pembelajaran langsung.

Pengujian hipotesis kedua dan ketiga dilakukan dengan test of betweensubjects effects. Rekapitulasi hasil test of between-subjects effects disajikan pada Tabel 3.

Tabel 3 Rekapitulasi Hasil Test of Between-Subjects Effects

\begin{tabular}{|c|c|c|c|c|c|c|}
\hline Source & $\begin{array}{l}\text { Dependent } \\
\text { Variable }\end{array}$ & $\begin{array}{l}\text { Type III Sum } \\
\text { of Squares }\end{array}$ & Df & Mean Square & $\mathrm{F}$ & Sig. \\
\hline Corrected & Sikap IImiah & $5110,655^{a}$ & 3 & 1703,552 & 51,098 & 0,000 \\
\hline
\end{tabular}




\begin{tabular}{|c|c|c|c|c|c|c|}
\hline Model & Berpikir Kritis & $5423,772^{b}$ & 3 & 1807,924 & 58,739 & 0,000 \\
\hline \multirow[t]{2}{*}{ Intercept } & Sikap IImiah & 2087,674 & 1 & 2087,674 & 62,619 & 0,000 \\
\hline & Berpikir Kritis & 1337,613 & 1 & 1337,613 & 43,459 & 0,000 \\
\hline \multirow[t]{2}{*}{ KSI } & Sikap Ilmiah & 224,158 & 1 & 224,158 & 6,724 & 0,012 \\
\hline & Berpikir Kritis & 22,421 & 1 & 22,421 & 0,728 & 0,397 \\
\hline \multirow[t]{2}{*}{ KBK } & Sikap IImiah & 0,391 & 1 & 0,391 & 0,012 & 0,914 \\
\hline & Berpikir Kritis & 2573,781 & 1 & 2573,781 & 83,621 & 0,000 \\
\hline \multirow[t]{2}{*}{ MP } & Sikap Ilmiah & 3692,787 & 1 & 3692,787 & 110,764 & 0,000 \\
\hline & Berpikir Kritis & 1083,693 & 1 & 1083,693 & 35,209 & 0,000 \\
\hline \multirow[t]{2}{*}{ Error } & Sikap IImiah & 1866,995 & 56 & 33,339 & & \\
\hline & Berpikir Kritis & 1723,628 & 56 & 30,779 & & \\
\hline \multirow[t]{2}{*}{ Total } & Sikap IImiah & 384763,000 & 60 & & & \\
\hline & Berpikir Kritis & 308756,000 & 60 & & & \\
\hline \multirow[t]{2}{*}{ Corrected Total } & Sikap Ilmiah & 6977,650 & 59 & & & \\
\hline & Berpikir Kritis & 7147,400 & 59 & & & \\
\hline
\end{tabular}

Berdasarkan Tabel 3, dapat disajikan interpretasi-interpretasi sebagai beerikut.

Pertama, dari sumber pengaruh $\mathrm{KSI}$ terhadap variabel sikap ilmiah, ditemukan nilai statistic $F=6,724$ dengan angka signifikan 0,012 dan terhadai berpikir kritis dengan $F=0,728$ dengan angka signifikansi 0,397 . Hal ini menunjukkan bahwa KSI hanya berpengaruh secara signifikan terhadap sikap ilmiah, tetapi tidak ada pengaruh signifikansi terhadap berpikir kritis.

Kedua, dari sumber pengaruh KBK terhadap variabel sikap ilmiah ditemukan $F=0,012$ dengan angka signifikansi 0,914 dan terhadap variabel berpikir kritis dengan $F=83,621$ dengan angka signifikan 0,001. Hal ini menunjukkan bahwa KBK tidak berpengaruh signifikan teradap sikap sikap ilmiah, tetapi berpengaruh signifikan terhadap berpikir kritis.

\section{PEMBAHASAN}

Berdasarkan hasil analisis deskriptif dan analisis MANCOVA, maka dapat diambil suatu justifikasi bahwa model pembelajaran sains teknologi masyarakat memberikan pengaruh yang lebih baik dibandingkan dengan model pembelajaran langsung. Model
Ketiga, dari sumber pengaruh MP terhadap kemampuan berpikir kritis siswa, menunjukkan harga statistik $F=35,209$ dengan angka signifikansi 0,001 yang lebih kecil dari 0,05 , sehingga $\mathrm{H}_{0}$ ke-2 ditolak. Jadi, terdapat perbedaan kemampuan berpikir kritis antara siswa yang belajar dengan model pembelajaran sains teknologi masyarakat dan siswa yang belajar dengan model pembelajaran langsung.

Keempat, dari sumber pengaruh MP terhadap sikap ilmiah menunjukkan harga statistik $F=110,764$ dengan angka signifikansi 0,001 yang lebih kecil dari 0,05 , sehingga $H_{0}$ ke-3 ditolak. Jadi, terdapat perbedaan sikap ilmiah antara siswa yang belajar dengan model pembelajaran sains teknologi masyarakat dan siswa yang belajar dengan model pembelajaran langsung.

pembelajaran sains teknologi masyarakat lebih baik dari model pembelajaran langsung dilihat dari segi landasan teoritis karena model sains teknologi masyarakat memiliki tahapan-tahapan pembelajaran yang lebih kompleks dan komprehensif 
dalam mengembangkan kemampuan berpikir kritis dan sikap terhadap sains.

Model pembelajaran sains teknologi masyarakat mampu memberdayakan siswa secara optimal, artinya pembelajaran tersebut tidak mengharuskan siswa untuk menghafal konsep-konsep, prinsip-prinsip, teori-teori tetapi mampu mendorong siswa untuk mengkonstruksi pengetahuan mereka sendiri sehingga mampu menerapkan pengetahuan tersebut untuk memecahkan masalah dan mengambil keputusan tentang masalah-masalah dalam masyarakat. Model pembelajaran sains teknologi masyarakat mengutamakan keterlibatan siswa dalam mencari dan mengidentifikasi informasi yang dapat digunakan untuk memecahkan masalahmasalah sosial dan teknologi, meningkatkan kesadaran siswa akan dampak ilmu pengetahuan alam dan teknologi, dan memperluas wawasan siswa mengenai ilmu pengetahuan alam lebih dari sesuatu yang perlu dikuasai untuk lulus ujian semata sehingga pembelajaran lebih bermakna. Hal ini sesuai dengan pernyataan Poedjiadi, (1994) bahwa STM menitikberatkan pada penyelesaian masalah dan proses berpikir yang melibatkan transfer jarak jauh yang artinya menerapkan konsep yang diperoleh di sekolah pada situasi di luar sekolah, yaitu yang ada di masyarakat.

Model pembelajaran sains

teknologi masyarakat merupakan model pembelajaran yang berakar pada paham konstruktivistik, yaitu model pembelajaran yang berpusat pada siswa. Dalam kegiatan pembelajaran siswa terlihat aktif dalam membangun pengetahuannya. Siswa dibiasakan untuk mengidentifikasi masalah-masalah beserta dampaknya, menggunakan sumber-sumber setempat (nara sumber dan bahan-bahan) untuk memperoleh informasi yang dapat digunakan dalam pemecahan masalah, menekankan keterampilan proses sains agar dapat digunakan oleh peserta didik dalam mencari solusi terhadap masalahnya.

Model pembelajaran sains teknologi masyarakat dapat menyiapkan siswa yang literasi sains dan teknologi. Siswa yang literisasi sains dan teknologi memiliki pengetahuan yang cukup tentang fakta, konsep, dan teori sains serta kemampuan mengaplikasikannya. Dalam membuat keputusan sehari-hari ia menggunakan konsep-konsep sains, keterampilan proses sains, dan nilai-nilai sains. Menyadari keunggulan dan keterbatasan sains dan teknologi dalam meningkatkan kesejahteraan masyarakat. Menyadari dan memahami interrelasi dan saling ketergantungan (interdependency) antara sains, teknologi, dan masyarakat. Mengenal sumber-sumber sains dan teknologi yang dapat dipercaya dan menggunakannya dalam membuat keputusan. Memahami dan dapat mengantisipasi dampak-dampak negatif sains dan teknologi. Dapat membedakan antara bukti-bukti ilmiah dan pendapat pribadi. Memiliki pandangan yang luas dan mendalam tentang dunia realita berkat pendidikan sins yang diperolehnya. Memiliki pengetahuan dan pengalaman yang cukup tentang sains sehingga ia dapat menghargai penelitian dan pengembangan teknologi. Mempertimbangkan aspek politik, ekonomi, moral, dan etika dari sains dan teknologi dalam hubungannya dengan isu personal dan global. Memiliki kemampuan sebagai pengambil keputusan (decision maker) dan Memiliki sikap yang positif terhadap sains dan teknologi (Yager,1996).

Model pembelajaran sains teknologi masyarakat mengacu pada teori Ausubel tentang belajar bermakna. Belajar bermakna merupakan suatu proses mengaitkan informasi baru pada konsep-konsep yang relevan yang terdapat dalam struktur kognitif seseorang (Dahar, 2011). Belajar bermakna membantu siswa menanamkan pengetahuan baru yang diperlukan untuk membentuk konsep awal yang sudah dimiliki siswa yang berkaitan dengan konsep yang akan diajarkan. Melalui cara ini, dalam diri siswa akan terjadi proses belajar karena siswa dihadapkan suatu aktifitas yang nyata dalam memecahkan 
suatu masalah sehingga terbentuk pengetahuan.

$$
\text { Pengembangan kemampuan }
$$

berpikir kritis dan sikap ilmiah dengan model pembelajaran sains teknologi masyarakat menekankan pada proses membangun makna dari pengalaman dalam mencari isu-isu sains dan teknologi dalam masyarakat serta mencari solusi untuk memecahkan masalah-masalah sosial dan teknologi. Proses tersebut tampak pada empat tahapan dalam model pembelajaran sains teknologi masyarakat, yaitu tahap invitasi; tahap eksplorasi, tahap pengajuan eksplanasi dan solusi, serta tahap pengambilan tindakan.

$$
\text { Keempat tahapan tersebut }
$$

memberi kesempatan kepada siswa untuk mengungkapkan kejadian-kejadian atau isu-isu yang ditemui di masyarakat baik melalui media cetak, elektronik maupun pengalaman pribadi. Siswa kemudian mencari data dari berbagai sumber informasi (buku, Koran, majalah, nara sumber, atau melakukan percobaan) untuk mencari jawaban dari isu-isu yang sudah ditemukan. Siswa diajak mengkomunikasikan gagasan yang diperoleh dari analisis informasi yang didapat, mendiskusikan solusi yang diperoleh, dan menentukan beberapa solusi. Kemudian siswa membuat suatu keputusan, penerapan pengetahuan dan keterampilan, serta membagi informasi dan gagasan. Dengan mengintegrasikan keempat tahapan ini dalam suatu proses pembelajaran, maka sangat dimungkinkan untuk meningkatkan kemampuan berpikir kritis dan sikap terhadap sains siswa menjadi lebih baik.

$$
\text { Tahapan pertama, guru }
$$

merangsang peserta didik mengingat atau menampilkan kejadian-kejadian yang ditemui di masyarakat baik melalui media cetak maupun media elektronik yang berkaitan dengan topik yang merupakan hasil observasi. Tahapn kedua, peserta didik merupakan upaya untuk mencari jawaban atau menguji jawaban sementara yang telah dibuat dengan mencari data dari berbagai sumber informasi (buku, koran, majalah, lingkungan, nara sumber, instansi terkait, atau melakukan percobaan). Hasil yang diperoleh peserta didik hendaknya berupa suatu hasil analisis dari data yang diperoleh. Kegiatan peserta didik pada tahap ini diantaranya dapat berupa tukar pendapat, mencari informasi, bereksperimen, mengobservasi fenomena khusus, mendesain model/karya, dan mendiskusikan pemecahan masalah.

Tahapan ketiga, peserta didik diajak untuk mengkomunikasikan gagasan yang diperoleh dari analisis informasi yang didapat, menyusun suatu model penjelasan (baru), meninjau dan mendiskusikan solusi yang diperoleh, dan menentukan beberapa solusi. Tahap keempat, peserta didik diajak untuk membuat suatu keputusan dengan mempertimbangkan penguasaan konsep sains dan keterampilan yang dimiliki untuk berbagi gagasan dengan lingkungan, atau dalam kedudukan peserta didik sebagai pribadi atau sebagai anggota masyarakat.

Berpikir kritis adalah suatu proses yang kompleks yang melibatkan penerimaan dan penguasaan data, analisis data, dan evaluasi data dengan mempertimbangkan aspek kualitatif dan kuantitatif serta melakukan seleksi atau membuat keputusan berdasarkan hasil evaluasi.. proses ini akan terwujud jika diterapkan suatu model pembelajaran yang menekankan pada proses membangun pengetahuan secara mandiri. Komponen-komponen berpikir kritis yang dikembangkan meliputi memfokuskan pertanyaan, menganalisis pertanyaan, bertanya dan menjawab pertanyaan tentang suatu penjelasan, mempertimbangkan, mengamati, mendeduksi, menginduksi, membuat dan menentukan pertimbangan, mendefinisikan, menentukan tindakan, dan berinteraksi dengan orang lain.

Model pembelajaran sains teknologi masyarakat sangat relevan diterapkan untuk mengembangkan kemampuan berpikir kritis. Tahap invitasi dapat mengembangkan kemampuan untuk mengidentifikasi mengenai masalah atau pertanyaan, mengamati dan membuat serta menentukan pertimbangan. Tahap eksplorasi, dapat 
mengembangkan kemampuan untuk mencari informasi, bereksperimen, mengobservasi, mendesain model, dan mendiskusikan pemecahan masalah. Tahap pengajuan eksplanasi dan solusi dapat mengembangkan kemampuan bertanya dan menjawab pertanyaan tentang suatu penjelasan, mendeduksi dan menginduksi. Tahap pengambilan tindakan dapat mengembangkan kemampuan menentukan pertimbangan dan menetukan tindakan.

Sikap ilmiah dapat dikembangkan dengan baik jika diterapkan suatu model pembelajaran menekankan pada pengalaman yang mengembangkan kemampuan dasar untuk memperoleh pengetahuan tentang produk sains, berupa konsep-konsep, prinsip-prinsip, hukum-hukum, dan teori-teori sains. Komponen-komponen sikap ilmiah yang dikembangkan meliputi rasa ingin tahu, respek terhadap fakta, berpikir kritis, penemuan dan kreativitas, berpikiran terbuka dan kerjasama, ketekunan, dan peka terhadap lingkungan sekitar. Model pembelajaran sains teknologi masyarakat sangat relevan diterapkan untuk mengembangkan sikap ilmiah. Tahap invitasi dapat mengembangkan sikap respek terhadap fakta. Tahap eksplorasi dapat mengembangkan sikap rasa ingin tahu. Tahap pengajuan eksplanasi dan solusi dapat mengembangkan sikap berpikir kritis, penemuan dan kreativitas, berpikiran terbuka dan kerjasama, serta ketekunan. Tahap pengambilan tindakan dapat mengembangkan sikap peka tehadaplingkungan sekitar.

Secara keseluruhan, tahapantahapan model pembelajaran sains teknologi masyarakat dapat mengembangkan kemampuan berpikir kritis dan sikap ilmiah siswa yang lebih baik. Model pembelajaran sains teknologi masyarakat memberi kesempatan kepada siswa untuk belajar mengalami, mengungkapkan, mengembangkan atau menerapkan, dan mengaitkan konsepsikonsepsi baru dengan isu-isu sains dan teknologi. Siswa tidak hanya sekedar menghafal konsepsi-konsepsi baru tersebut melainkan aktif, kreatif dalam proses pembelajran dan siswa dapat menghasilkan kemampuan aplikasi dalam kehidupan. Hal inilah yang menjadi keunggulan model pembelajaran sains teknologi masyarakat dibandingkan model pembelajaran langsung.

Kedua, secara empiris keunggulan model pembelajaran sains teknologi masyarakat dalam hal pencapaian kemampuan berpikir kritis dan sikap terhadap sains didukung oleh hasil penelitian yang dilakukan oleh Arifin (2015) menunjukkan skor rata-rata kemampuan berpikir kritis dan sikap terhadap sains yang diperoleh kelompok siswa yang mengikuti model pembelajaran STM yakni lebih besar daripada siswa yang mengikuti model pembelajaran langsung. Nurlitasari (2015) menunjukkan bahwa terjadi peningkatan hasil belajar siswa dan peningkatan sikap peduli lingkungan.

Berdasarkan pemaparan tersebut dapat diambil suatu generalisasi bahwa model pembelajaran sains teknologi masyarakat lebih cocok diterapkan daripada model pembelajaran langsung dalam pengembangan kemampuan berpikir kritis dan sikap ilmiah. Model pembelajaran sains teknologi masyarakat sangat direkomendasikan oleh peneliti mengingat ciri dan karakteristik model pembelajaran ini mampu meningkatkan indikator-indikator kemampuan berpikir kritis dan sikap ilmiah.

\section{SIMPULAN DAN SARAN}

Berdasarkan hasil penelitian dan pembahasan, maka dapat diuraikan tiga simpulan yang merupakan jawaban terhadap tiga masalah yang diajukan dalam penelitian ini, yaitu: (1)Terdapat perbedaan kemampuan berpikir kritis dan sikap ilmiah antara siswa yang mengikuti model pembelajaran sains teknologi masyarakat dengan siswa yang mengikuti model pembelajaran langsung setelah perlakuan dikontrol dengan kemampuan berpikir kritis awak dan sikap ilmiah awal; (2)Terdapat perbedaan kemampuan berpikir kritis antara siswa yang mengikuti model pembelajaran sains teknologi masyarakat dengan siswa yang mengikuti 
model pembelajaran langsung setelah perlakuan dikontrol dengan kemampuan berpikir kritis awal; (3)Terdapat perbedaan sikap ilmiah antara siswa yang mengikuti model pembelajaran sains teknologi masyarakat dengan siswa yang mengikuti model pembelajaran langsung setelah perlakuan dikontrol dengan sikap ilmiah awal.

Saran-saran yang dapat disampaikan dalam penelitian ini adalah sebagai berikut. (1). Hasil penelitian menunjukkan bahwa siswa yang belajar dengan model pembelajaran sains teknologi masyarakat secara signifikan memiliki kemampuan berpikir kritis dan sikap ilmiah yang lebih tinggi daripada siswa yang belajar dengan model pembelajaran langsung. Untuk itu model ini hendaknya diperkenalkan dan dikembangkan kepada pendidik guna meningkatkan kemampuan berpikir kritis dan sikap ilmiah siswa. (2) Berdasarkan hasil temuan bahwa model pembelajaran STM memiliki pengaruh yang signifikan terhadap kemampuan berpikir kritis dan sikap ilmiah. Untuk itu dapat disarankan bahwa dalam pembelajaran yang lebih mengutamakan kemampuan berpikir kritis dan sikap ilmiah sebaiknya guru menggunakan model pembelajaran dengan membentuk kelompok-kelompok dalam proses pembelajaran sehingga dengan model ini siswa lebih aktif dalam mengungkapkan pengalaman dalam belajar. (3) Penelitian ini menggunakan model pembelajaran sains teknologi masyarakat yang merupakan model pembelajaran berpaham konstruktivisme. Untuk memperkaya studi tentang model pembelajaran yang sesuai untuk

\section{DAFTAR PUSTAKA}

Arikunto, S. 2010. Prosedur penelitian. Jakarta: Rineka Cipta.

BNSP. 2006. Panduan penyusunan kurikulum tingkat satuan pendidikan jenjang pendidikan dasar dan menengah. Jakarta: BNSP.

Dahar, R. W. 1989. Teori-Teori Belajar. Jakarta: Erlangga. mengatasi permasalahan yang terkait dengan kemampuan berpikir kritis dan sikap ilmiah, disarankan kepada peneliti lain agar diadakan penelitian lebih lanjut terkait dengan model pembelajaran lainnya yang menganut paham konstruktivisme. (4) Penelitian ini hanya difokuskan untuk menyelidiki pengaruh model pembelajaran sains teknologi masyarakat terhadap kemampuan berpikir kritis dan sikap ilmiah. Oleh karena itu, disarankan kepada peneliti lain agar diadakan penelitian lebih lanjut terkait dengan pengaruh model pembelajaran sains teknologi masyarakat dalam pembelajaran sains terhadap variabelvariabel lain. Misalnya, konsep diri, keterampilan proses, keterampilan berpikir kreatif, keterampilan pemecahan masalah, dan lain sebagainya. (5) Penelitian ini menghasilkan perangkat pembelajaran (RPP dan LKS) model pembelajaran sains teknologi masyarakat yang telah teruji secara empirik kelayakan dan keunggulannya sebagai perangkat pembelajaran IPA di SMP. Disarankan kepada peneliti lain agar diadakan penelitian pengembangan perangkat pembelajaran berbasis model sains teknologi masyarakat seperti pengembangan bahan ajar berbasis sains teknologi masyarakat.

\section{UCAPAN TERIMA KASIH}

Pada kesempatan ini, penulis ingin menyampaikan terima kasih kepada:

1. Prof. Dr. I Wayan Santyasa, M.Si.

2. Dr. I Made Kirna, M.Si. atas bimbingannya dalam penyusunan jurnal ini

Desianti, N. W. H., Adnyana, P. B., \& Setiawan I. G. A. N. 2015. Pengembangan perangkat pembelajaran IPA dengan setting sains teknologi masyarakat untuk meningkatkan keterampilan proses sains dan keterampilan berpikir kreatif siswa SMP. e- Journal Program Pascasarjana Universitas Pendidikan Ganesha Program 
Studi Pendidikan IPA. 5: 1-12. Tersedia pada http://pasca. undiksha.ac.id. Diakses 6 Februari 2016.

Depdiknas. 2006. Panduan penyusunan kurikulum tingkat satuan pendidikan jenjang pendidikan

dasar dan menengah. Jakarta: Badan Standar Nasional.

Kardi, S. \& Nur, M. 2004. Pengajaran langsung. Surabaya: University Press.

Kartini, N. N, Adnyana, P.B., \& Jelantik, I. B. S. 2014. Pengaruh pendekatan pembelajaran sains teknologi masyarakat (STM) terhadap kemampuan pemecahan masalah dan sikap ilmiah siswa. e-Journal Program Pascasarjana Universitas Pendidikan Ganesha Program Studi IPA. 4: 1-13. Tersedia pada http://pasca.undiksha.ac.id/ejournal lindex.php/jurnal. $\quad$ Diakses 11 Februari 2016.

Poedjiadi, A. 2005. Sains teknologi masyarakat (model pembelajaran kontekstual bermuatan nilai). Bandung: PT. Rosdakarya.

Rafiuddin, A. 2011. Penilaian sikap ilmiah dalam pembelajaran sains. Artikel. Tersedia pada www.depdiknas. go.id/jurnal/27/Sikap_ilmiah.

Diakses 23 Maret 2016.

Sadya, W. 2011. Model pembelajaran sains teknologi masyarakat. Singaraja: Universitas Pendidikan Ganesha.

Santoso, S. 2010. Statistik multivariat. Jakarta: PT Elex Media Komputindo.

Santyasa, I W. 2012. Pembelajaran inovatif. Singaraja: Universitas Pendidikan Ganesha.
Santyasa, I W. 2014. Asesmen dan evaluasi pembelajaran fisika. Yogyakarta: Graha Ilmu.

Suparno, P. 1997. Filsafat konstruktivisme dalam pendidikan. Yogyakarta: Kaniasius.

Yager, R. $\quad$ E. 1996.

Sciens/technology/society as reform in science education. New York: State University 